児童体位の年次観察による地域評価

東 博 文* 坂 本 眞一郎** 相 良徹***
銅 谷

\title{
Evaluation of Community Health Status Using Data Obtained by Longitudinal Observation of Physical Status of School Children
}

\section{Hirofumi HIGASHI*, Shinichirou SAKAMOTO**, Tohru SAGARA*** and Shin DOUYA****}

A study to describe physical status of school children (6-7 years old) in Kakegawa City, Sizuoka Prefecture was investigated, based on data of height, weight, circumference of the chest, body-trunk, sitting height, $120 \%$ over weight (for height) and Rohrer's Index.

Longitudinal survey from 1971 to 1979 shows;

1) Smaller physical status compared with average national figure.

2) Shorter legs as compared to the body-trunks among school children surveyed.

3) An increasing number (yearly) of over weight among school children.

The study proposes a development of a maternal education program through an integration of school health survey and maternal and child health program.

\section{I.はじめに}

近年の学童における体位はめざましく向上して きた.この学童体位の向上は食生活の向上や生活 様式の变化などが背景にあると言われている.

学童体位の向上はめざましいものの, 逆に学童 肥满傾向児の出現や体位の地域格差などが問題点 として指摘され，その対応策がとられつつある. そこで静岡県のある市における学童体位の年次推 移を観察し，文献的検討による考察を試みたので
報告する。

\section{II 方 法}

（1）対象：1971年〜1979年までの 9 年間におけ る小学校 1 年生総数を対象とした。資料はこれら の年次に行なわれた就学時健康診断で測定された 体格測定值と, これと比較するための文部省学校 保健統計調査報告書（1971 1979年）の全国平均 値及び東京平均値を用いた。

当該市は16の行政地区からなり，市内には16校

* 国立水俣病研究センター疫学研究部

** 昭和大学医学部公衆衛生学教室

*** 日本大学歯学部衛生学教室

***** 帝京大学医学部公衆衛生学教室

* Depertment of Epidemiology, National Instiute for Minamata Disease

** Depertment of Public Health, Showa University School of Medicine

*** Depertment of Hygiene and Health, Nihon University School of Dentistry

**** Depertment of Public Health, Teikyo University School of Medicine 
表 1 年次ごとの群別児童数

\begin{tabular}{ccccccc}
\hline 年次 & 総 & 数 & \multicolumn{2}{c}{ 人口密集地区群 } & \multicolumn{2}{c}{ 人口希薄地区群 } \\
\hline & 男 & 女 & 男 & 女 & 男 & 女 \\
\hline 1971 & 486 & 457 & 395 & 372 & 91 & 85 \\
'72 & 400 & 426 & 328 & 350 & 72 & 76 \\
'73 & 387 & 366 & 323 & 316 & 64 & 50 \\
'74 & 545 & 496 & 457 & 406 & 88 & 90 \\
'75 & 481 & 490 & 415 & 415 & 66 & 75 \\
'76 & 511 & 486 & 423 & 409 & 88 & 77 \\
'77 & 447 & 440 & 386 & 361 & 61 & 79 \\
'78 & 552 & 494 & 467 & 424 & 85 & 70 \\
'79 & 600 & 547 & 509 & 454 & 91 & 93 \\
\hline
\end{tabular}

が存在するが，1行政地区に必ずしも 1 校が設置 されている状況ではない，そこで，当該地域内の 比較を目的として, 人口密度による小学校の群別 を行なった。すなわち, 人口密度が 301 人 $/ \mathrm{km}^{2}$ 以上 の地区を人口密集地区群とし, 人口密度が 300 人/
図 1 各種の体格指標

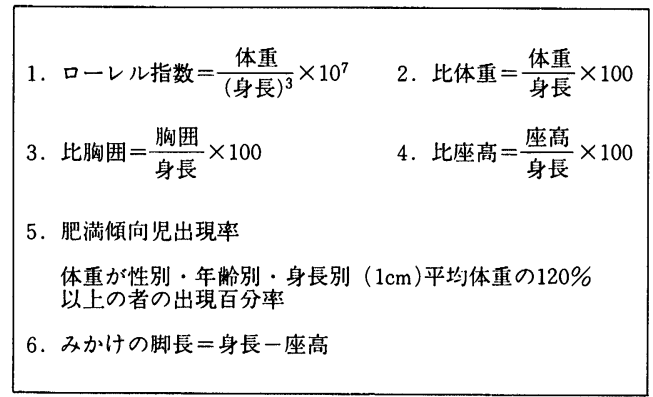

$\mathrm{km}^{2}$ 以下の地区を人口希薄地区群とした。人口密 集地区内には11校, 人口希薄地区内には 5 校がみ られた。これら群別児童数は表 1 に示すように, 多年次ともに，それぞれ 1,000 人前後，および200 人弱の児童数がみられる.

（2）調查項目：全国平均値と東京平均値は身

図 2 全国・東京及び当該地域における性別身長と体重の年次推移

身䦂
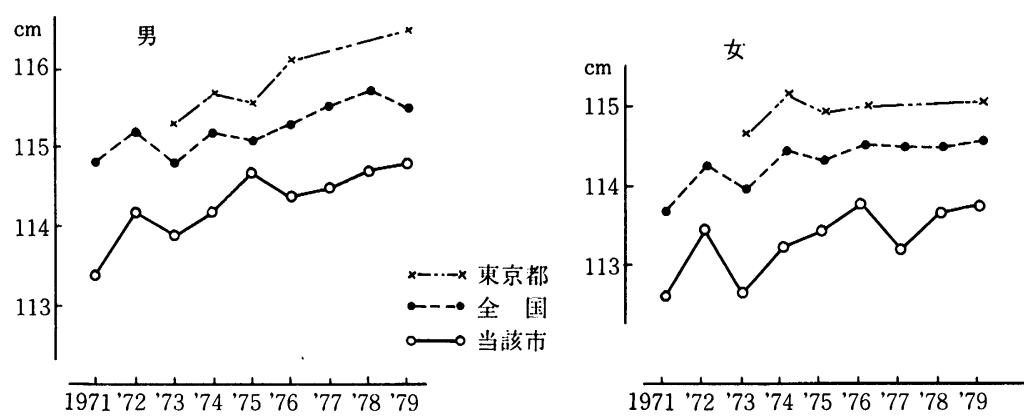

体 重

x-・-x 東京都

--. 全 国

○当硋市
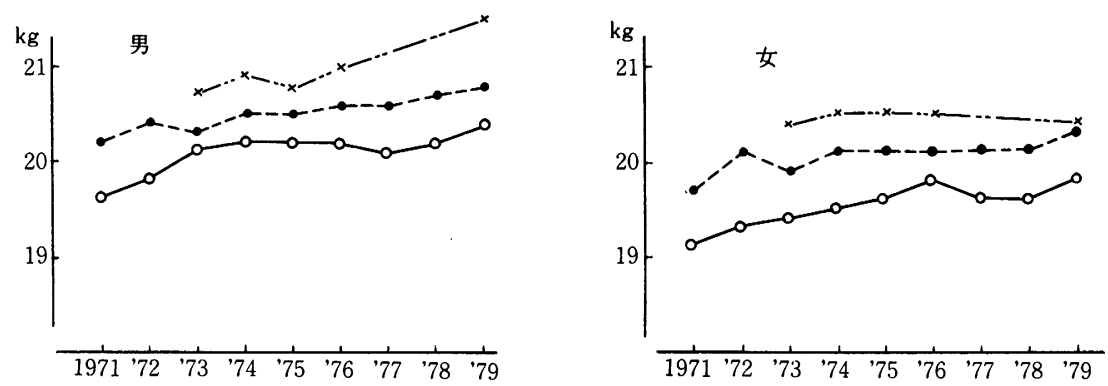
長，体重を取り扱った。当該市については身長， 体重, 胸囲, 座高及びこれから算出される比体重, 比胸囲, 比座高, みかけの脚長, ローレル指数, そして対象児童全数を用いた肥満傾向児出現率 （図 1 に示す）を取り扱った。

（3）分析：当該市に括ける年次ごとの身長，体 重, 胸囲, 座高について, 性別に群間の平均値の 差の検定を行なった。 また群・性別身長, 体重, 胸囲, 座高, 比体重, 比胸囲, 比座高, 又かけの 脚長, ローレル指数間の内部相関分析を行なった。

\section{III 結 果}

(1) 体位の年次推移

全国，東京，当該市に扣ける性別身長と体重の
平均值を示すと図 2 の傾向がみられる。当該市は いずれの年次においても，男女ともに全国，東京 を下回った値を示し，著しい低体位が観察された。

（2）当該市における体位の年次推移と群間比較 身長は，図 3 に示されるように，男女ともに顕 著ではないが，わずかに増加傾向がみられる。男 子の場合, '72年と'75年以外の他の年次で, 人口密 集地区群に比べて人口希薄地区群が下回って拉 り, '76・'79年には有意差 $(\mathrm{p}<0.05)$ がみられた。 女子では’71年以外の, 各年次で男子と同様に人口 密集地区群に比べて人口希薄地区群が下回ってい るが，有意差はなかった。

体重は, 身長に比べて, その増加傾向は顕著で はないが，わずかに増加の傾向にある。

図 3 群別当該地域に拈ける性別身長と体重の年次推移

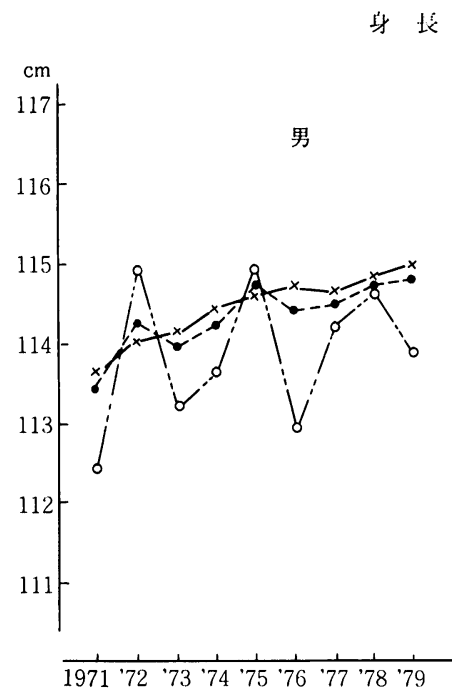

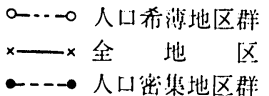



体 禾

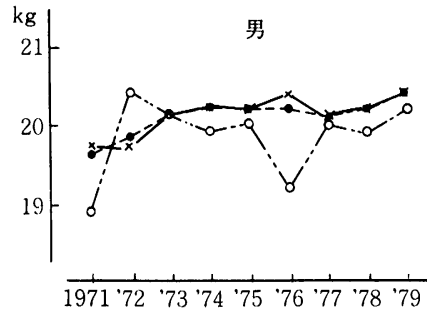

$\cdots \cdots$ 全 地 区 ○... - 人 人希沙地区群

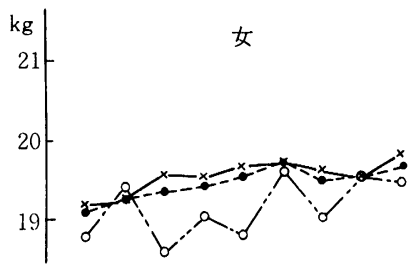

$\frac{1}{1971^{\prime} 72^{\prime} 73^{\prime} 74^{\prime} 75^{\prime} 76^{\prime} 77^{\prime} 78^{\prime} 79}$
×—×人口密雀地区群 


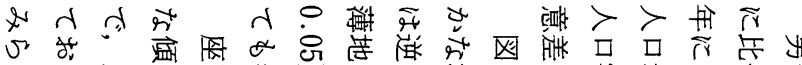

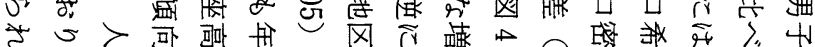

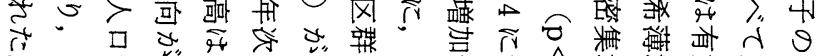

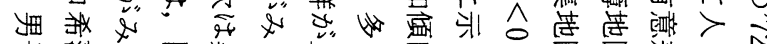

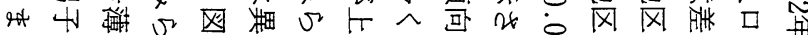
त

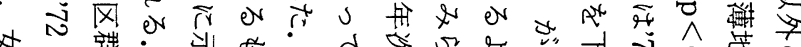
* m

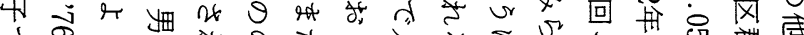

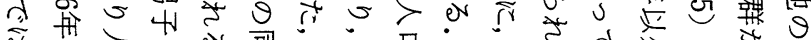

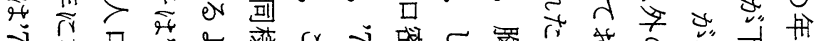

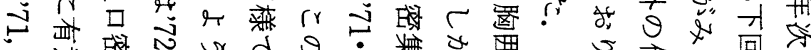
它地

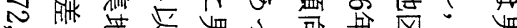

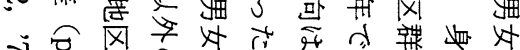

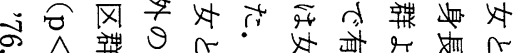
0 荗 范穴

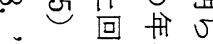

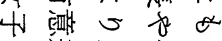

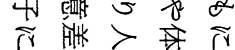

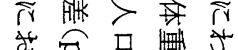
症向回 - $\theta$ त 4 कै तो के प $\because$ 告.

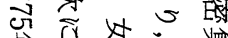

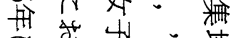

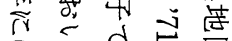
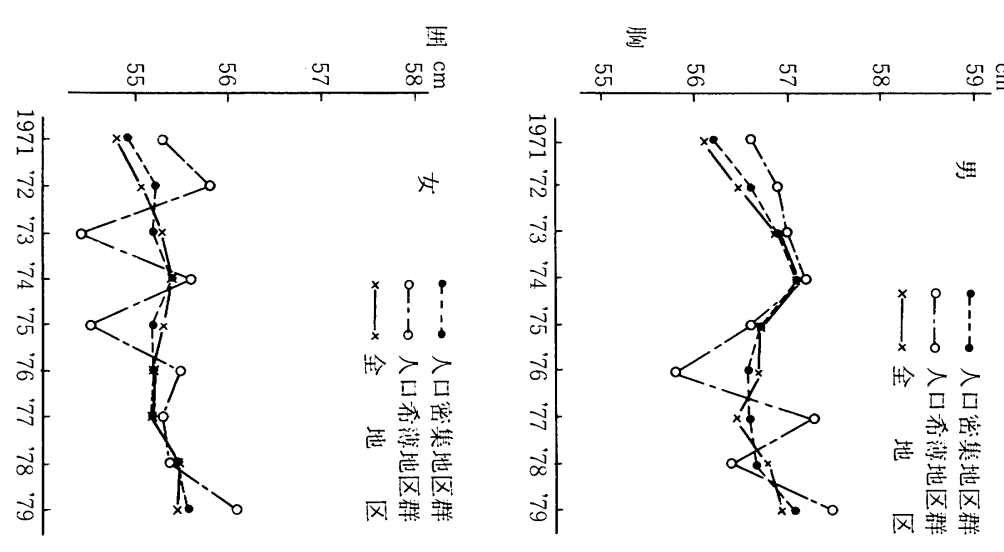

表 2 当該市における肥満傾向児の出現率と群別肥満傾向児の出現小学校数の推移

\begin{tabular}{|c|c|c|c|c|c|c|c|c|c|c|c|c|c|c|c|c|c|c|c|c|c|c|c|c|c|c|c|c|c|c|c|c|c|c|c|c|c|c|}
\hline & & & & & 口 & $x$ & & "ז. & 区 & 群 & & & & & & & 人 & & 口 & & 密 & & 集 & \pm & 地 & 区 & & 群 & & & & & & \multirow{2}{*}{\multicolumn{5}{|c|}{ 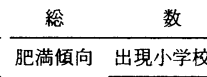 }} \\
\hline & & \multicolumn{9}{|c|}{ 各小学校の性別肥満傾向児出現率 } & \multicolumn{2}{|c|}{ 出現小学校 } & \multicolumn{18}{|c|}{ 各小学校の性別肥满傾向児出現率 } & \multicolumn{3}{|c|}{ 出現小学校 } & & & & & \\
\hline & & 1 & & 2 & 3 & 3 & 4 & 4 & 5 & & 合 & 計 & 1 & 2 & & 3 & & 4 & 5 & & 6 & & 7 & & 8 & & 9 & 10 & & 11 & & 合 & 計 & & 現率 & 合 & & 計 \\
\hline 次 & & 女 & 男 & 女 & 男 & 女 & 男 & 女 & 男 & 女 & 男 & 女 & 男 女 & 男 & 女 & 男 女 & 男 & 女 & 男 & 女 & 男 & 女 鳬 & 男 女 & 女 & 男 女 & 女 男 & 官 女 & 男 & 女 & 男 女 & 女 男 & 男 女 & & 男 & 女 & 男 & 女 & \\
\hline 1971 & - & - & - & - & - & - & - & - & - & - & - & - & -1.3 & - & - & - & - & 4.0 & - & - & -3 & 3.4 & - & - & -- & - & - & - & - & - & - & -3 & $\begin{array}{l}3 \\
3\end{array}$ & 1.2 & 1.5 & - & 3 & 3 \\
\hline '72 & - & - & - & - & - & - & - & - & - & - & - & - & -- & -1 & 1.4 & -- & - & - & - & - & -2 & 2.5 & - & - & -- & - & - & - & - & - & - & -2 & 22 & 0.2 & 1.9 & - & 2 & 2 \\
\hline '73 & - & - & - & - & 5.9 & - & - & - & - & - & 1 & - & -- & - & - & - & 2.4 & $4-$ & 4.2 & - & -- & -- & - & - & -- & -- & -- & - & - & - & $-\quad 2$ & $2-$ & -2 & 2.1 & 1.9 & 3 & - & 3 \\
\hline 74 & - & - & - & - & - & - & - & - & - & - & - & - & $3.0-$ & - & - & - & - & - & - & - & - & - & - & - & -4. & 4.86. & $2-$ & - & - & - & -1 & 12 & 23 & 0.7 & 1.6 & 1 & 2 & 3 \\
\hline 75 & - & - & - & - & - & - & - & - & - & - & - & - & $\begin{array}{lll}3.1 & 1.71\end{array}$ & 1.6 & - & -- & - & 2.9 & - & - & - & - & - & - & -3. & $3.8-$ & -- & - & - & - & 2 & 3 & $\begin{array}{ll}3 & 4\end{array}$ & 2.1 & 2.2 & 2 & 3 & 4 \\
\hline 76 & - & - & - & - & - & - & - & - & - & - & - & - & --2 & 2.72 & & 1.82 .3 & $3-$ & - & - & - & - & - & - & - & -- & -- & -- & - & - & - & $-\quad 2$ & $2 \quad 2$ & 22 & 2.0 & 1.2 & 2 & 2 & 2 \\
\hline 77 & - & - & - & - & - & - & - & - & - & - & - & - & 1.61 .6 & -1 & 1.2 & - & - & 4.0 & - & - & - & - & - & - & -- & - & -5.9 & - & - & -4 & $\begin{array}{ll}.0 & 1\end{array}$ & 15 & 5 & 1.1 & 2.7 & 1 & 5 & 5 \\
\hline 78 & - & - & - & - & - & - & - & - & - & - & - & - & -1.5 & -2 & 2.21 & $1.7-$ & & 94.2 & - & - & - & -3 & $3.8-$ & - & -- & - & -- & - & - & - & -3 & 3 & $\begin{array}{ll}3 & 5\end{array}$ & 2.5 & 1.6 & 3 & 3 & 5 \\
\hline 79 & - & - & - & - & - & - & - & - & - & - & - & - & 1.62 .7 & & 1.5 & -2.5 & & 3.3 & - & - & - & - & - & - & -2. & 2.63. & $1-$ & - & $-\varepsilon$ & $8.0-$ & $-\quad 4$ & 45 & 56 & 2.2 & 2.4 & 4 & 5 & 6 \\
\hline
\end{tabular}


図 5 群別当該地域における性別座高とみかけの脚長の年次推移

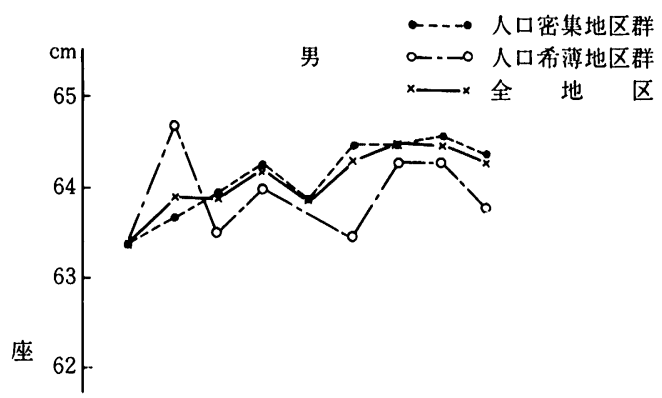

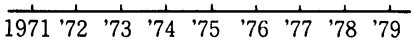

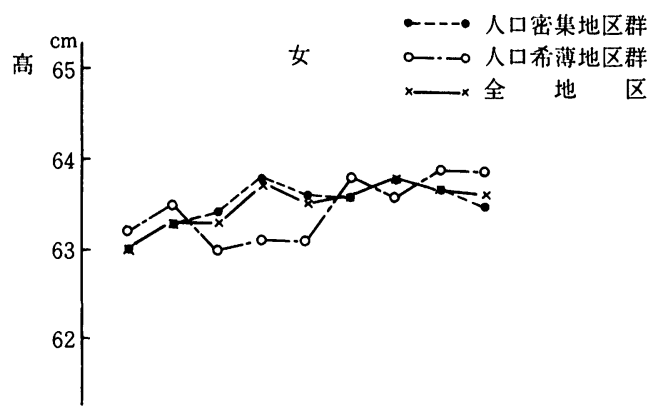

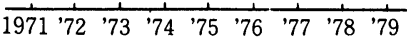

年以外の年次で，人口希薄地区群を上回っている ものの，有意差 $(\mathrm{p}<0.05)$ がみられたのは’74年の みであった。 また，みかけの脚長は男女ともに， その増減は横這い傾向にある。そして, 殆どの年 次で人口希薄地区群より人口密集地区群が上回る 傾向がみられたが，有意差はみられなかった。

（3）肥満傾向坚の出現状況

対象期間とした 9 年間において，いずれかの年 次で肥満傾向児の出現がみられた小学校数は人口 希薄地区群で1/5校, 人口密集地区群で10/11校で あった。 また，表 2 に示すように人口密集地区群 は年々男女ともに，その出現率は高くなる傾向が みられた。特に'79年の男子で最高 $8.0 \%$ ，及び 77 年の女子では最高 $5.9 \%$ みかられた。

\section{（4）体格指標の内部相関}

図 6，7 に示すよらに，男女とも人口希薄地区 群之人口密集地区群の多くの体格指標間に正負の 有意相関がみられた。すなわち，人口希薄地区群， または人口密集地区群のいずれにも相関関係が認

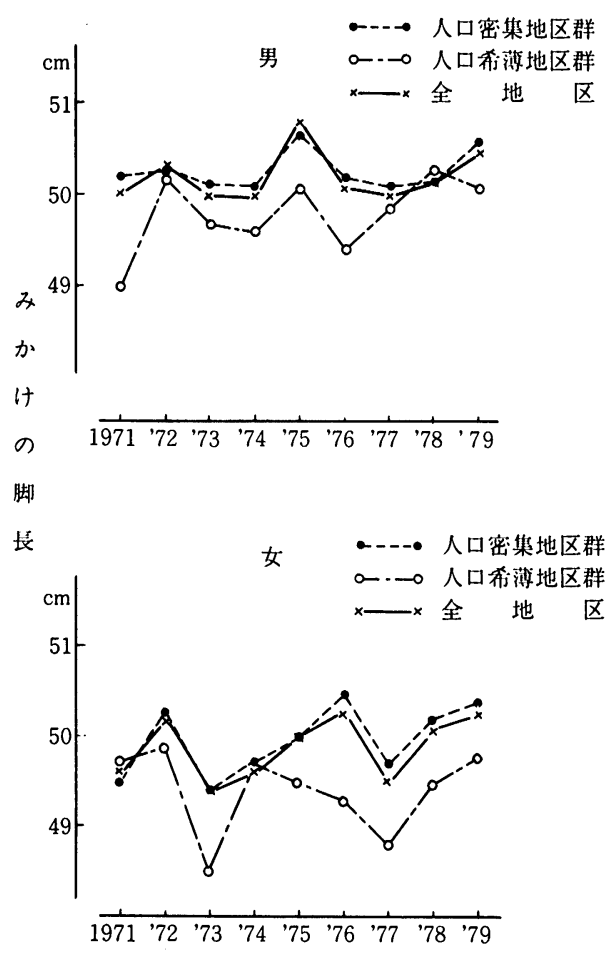

められた格格指標の組み合わせは，男子で身長と 体重, 身長と座高, 体重と比体重, 胸囲と比体重, 女子では身長とみかけの脚長，体重と胸囲，体重 と座高, 体重と比体重, 比座高とみかけの脚長で あった。

一方，人口希薄地区群，または人口密集地区群 のいずれか一方にのみ，相関関係のあった組み合 わせは，人口希薄地区群で男子の場合に身長とみ かけの脚長 $(p<0.01)$, 胸囲と比胸囲 $(\mathrm{p}<0.05)$, ローレル指数と比胸囲 $(\mathrm{p}<0.05)$ の正の, 比座高 とみかけの脚長 $(\mathrm{p}<0.01)$ に負の相関関係がみら れた。また，人口密集地区群では座高と比体重 $(\mathrm{p}<0.05)$, 座高と比座高 $(\mathrm{p}<0.01)$, 口 $<$ ル指 数と比体重 $(\mathrm{p}<0.05)$ に正の相関関係がみられ た.

女子では人口希薄地区群で身長と体重 $(p<$ $0.01)$ ，身長之胸囲 $(p<0.01)$ ，身長之座高 $(p<$ $0.05)$ 胸囲と比体重 $(\mathrm{p}<0.05)$, 胸囲と比胸囲 $(\mathrm{p}<$ $0.05)$, 座高と比体重 $(\mathrm{p}<0.01)$ ，口ーレル指数と 
図 6 男子における体格指標の内部相関関係

人口希薄地区群

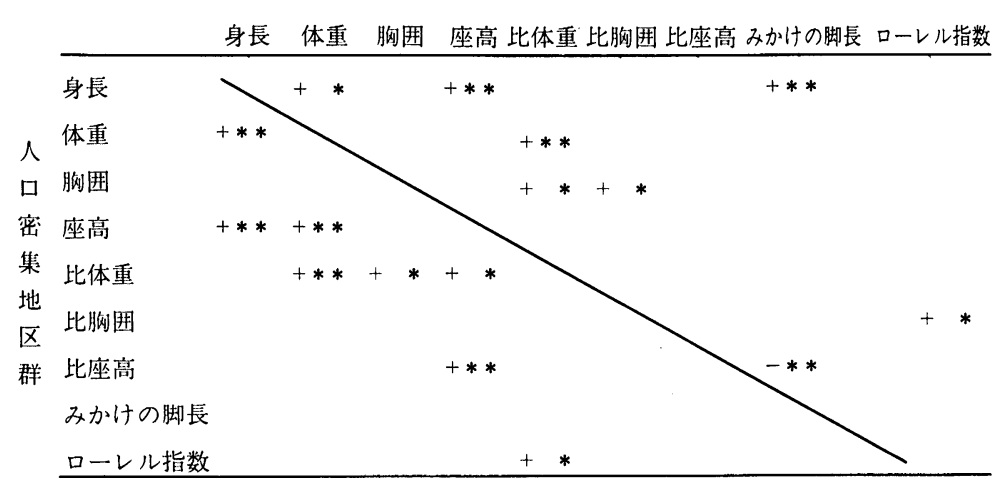

$(* \mathrm{p}<0.05, * * \mathrm{p}<0.01)$

図 7 女子に括ける体格指標の内部相関関係

人口希薄地区群

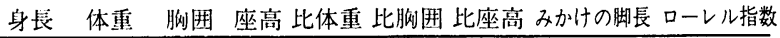

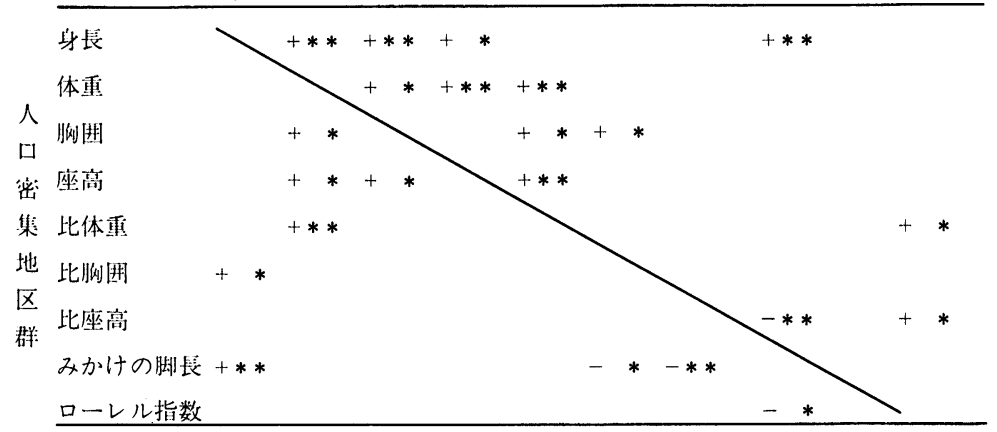

$(* \mathrm{p}<0.05, * * \mathrm{p}<0.01)$

比体重 $(\mathrm{p}<0.05)$, 比座高とローレル指数 $(\mathrm{p}<$ 0.05）で正の相関関係がみられた。 また，人口密 集地区群では身長と比胸囲 $(\mathrm{p}<0.05)$, 胸囲之座 高 $(\mathrm{p}<0.05)$ に正の比胸囲とみかけの脚長 $(\mathrm{p}<$ $0.05)$ ， 及かけの脚長とローレル指数 $(\mathrm{p}<0.05)$ で負の相関関係がみられた。

\section{IV 考察}

近年の児童体位の向上は著しいものがあると言 われている。ことに身長の著しい伸びは諸氏によ り報告されている。これらの研究は都道府県を単 位とする大きな集団を対象とした結果での一致し
た見解である、しかし，このような大きな集団で の結果は一市町村での学校保健対策上の参考資料 にはなるであろらが，実際には役立たないのが実 情である，地域の保健対策を推進するには，該当 地域に有用な統計指標が提供されなければならな いと考える。

国勢調査報告 (1980) によると人口が 100,000 以 下といった規模の市町村は極めて多く，また，保 健対策の実践としても，一般的単位としての活動 の展開が容易であろう.

そこで, 我が国に括ける学童体位の問題が，極 めて小さな地域内においても調査が可能であるか 
についての検討は意味あるものと考える。もし， 可能であるとするならば，小地域内のデータのみ で評価し，その対応策を検討することもできると 考え本調査を試みた。本調査地域の学校保健の特 徵的問題点としては, 全国や東京平均値に比べて 顕著な低体位があげられる。また，群別した人口 希薄地区群の低体位はさらに顕著であった。この 低体位に関しては，保健的立場からはより多くの 見解もあるが，児童の低体位は田中（1979）の報 告にみられるよらに児童の心身に影響を扣よぼす 可能珄も考えられ，今後検討を要する課題と考え ている.

体格指標の内部相関をみた結果から, 人口希薄 地区群の男子に拈いて，わずかではあるが身長の 伸びもみられ，それに伴ってみかけの脚長も伸び ている状況にあった。 しかし，人口希薄地区群の 男女を合わせても全児童数の $20 \%$ 弱に過ぎないこ とから，当該地域を代表していない，従って，体 型的には生山・他（1980）の報告にみられる胴短 長足の傾向にあるとは思われない.

一方, 人口密集地区群の場合, 男子においては 体重が増加するに伴って，座高も増加傾向にあっ た。また，女子でも体重の増加とともに胸囲や座 高も伸びていることから，体型的にはわずかに胴 長短足の傾向にあり, 下半身の発育よりも上半身 の発育がより優れているものと推察される.そし て, 人口密集地区群内児童は全体の約 $80 \%$ 占め, その中に高い肥満傾向览の出現がみられ，しかも 年々その率も増加している傾向にあることから， 当該地域の児童は漸次的肥満傾向が指摘される.

当該地域における，このような肥満傾向の出現 に対して, 学童の年齢階級別体位についての詳細 な検討は行なっていないが，長谷部・他（1981） の報告にみられるよらな戦災などのような影響は 考えられない:むしろ水野・他（1978）の報告に みられる狭い通婚圏も，その一つの要因であるよ らに思われるが, この点についても今後の詳細な 検討を有する。

また，松本・他（1980）の第一次産業就業人口 割合からみた検討結果を参考にするならば，当該
地域は対象児童の出生から小学校就学時までの期 間に，しかも東（1982）の報告からみて，都市化 につながるような急激な生活様式の変化，さらに は縣・他（1982）の報告にみられる都市化の波及 や栄養上の改善もなされていない状況にあると思 われる。そして，当該地域住民には厚生統計協会 （1969）の報告にも記されている慣習的心理として 根深く引き継がれている報徳運動があり，世相の 変化に対応した個々の家庭（核家族化）での，独 自の育児がなされたことも推察される。それが， このような肥満傾向児の出現要因となったとも考 えられるが明確ではない。

以上のことから，さらに検討を加えるならば， それは乳幼児期の肥満が学童期の肥満に熬がりを 持っていると報告している渡辺・他（1982）や平 均出生時体重を地域の健康指標の一つとして考え たとしている華表・他（1978）の報告を参考にす るならば，母性数育活動の必要性が指摘される。 また中村・他（1981）の報告にみられるように， いわゆる発育期における栄養, 特に離乳食, 幼児 食の母性教育活動も重要であろら。しかし，母子 保健的方面からのみの地域保健教育活動ではな く，小さな地域ではより連携活動が可能であろら ことが推察されることから, 当該調查結果（学校 保健調査結果) などと中村・他（1981）の結果（母 子保健調査結果）を組み合わせた密接な連携によ る保健活動が展開されることを望むところであ る.

\section{V ま と め}

学童の体位は食生活の向上や生活様式の変化な どに伴って著しく向上してきている。このような 背景のなかで肥満傾向児の出現や体位の地域差な どが問題点として指摘され，その対策がとられつ つある。このような，わが国における学童体位の 全国的レベルでの問題が, 極めて小さな地域内（人 ロ 7 万弱）に拈いても調査が可能であるかについ ての検討は意味あるものと考える. もし可能であ るとするならば, 小地域内のデータのみで評価し， その対応策を検討することも可能になる。 
そこで，1971 1979年の小学 1 年生全児童を対 象に行政地区の人口密度により群別し，その児童 の就学時健康診断計測值を資料として, 体格指標 や肥満傾向児の出現率を求め, その経年变化を観 察した。 その結果, 当該地域は著しい低体位がみ られ, 体型的には胴長短足傾向にあると考兄られ た。また，肥満傾向児の出現率は人口密集地区内 の小学校に多くがみられ, その出現校も多くなり, 出現率も年々高くなる傾向がみられた。

以上の結果から, 文献的検討により母子保健調 查結果と学校保健調査結果を組み合わせた, 密接 な連携による母性教育活動が展開されることが望 ましいと考えられた。

なお，本論の一部については第50回日本民族衛生学 会総会（昭和60年 7 月，東京）にて報告した。 また, 本調查に御協力下さいました掛川市教育委員長, 各小 学校校長並びに保健科教諭の諸先生方に深謝するとと もに，格別なる御尽力を頂いて㧊ります静岡保健管理 センター，掛川市農業協同組合に対して敬意を表する とともに, 御指導御㬮撻下さいむした山本幹夫医学博 士にお礼申し上げます。

\section{文献}

長谷部昭久, 寺田せつ子, 小島のり子, 松木秀明, 春 日 斉, 神田照代, 横山公通 (1978)：時代を背景と しての身長の統計的観察，民族衛生，44(1)，25-32 生山 匡, 荒尾 孝(1980)：相対成長からみた戦後の
青少年の脚長化に関する考察, 体力研究, 45, 35-48 東 博文 (1982)：生活環境がもたらす農婦の健康意 識と保健行動，日農医誌，30(6), 1040-1020

厚生統計協会(1968)：昭和44年 4 月, 静岡県体位, 体 力, 栄養摂取実態調查分析に関する研究報告書, 厚 統協第28号, 1-174

華表宏有, 土井 徹, 比嘉恵子(1978)：わが国の平均 出生時体重の年次推移 (保健所別単産, 複産合計), 日衛誌, 32(6), 725-735

縣 俊彦, 丸井英二, 豊川裕之, 前田和甫 (1982)：千 葉県大網白里町山辺地区の学童の体位の変遷一全国 值との比較を中心として一, 民族衛生, 48(2), 58-69 水野徳美, 岡本 学, 有泉 誠, 野原聖一, 岡田 晃 (1978）：閉鎖的山村における通婚圈とその变容過 程について，民族衛生，44(4), 158-164

松本健治, 三野 耕, 永井尚子, 宮田啓史, 工藤陽子, 庄本正男, 竹内宏一, 武田真太郎 (1980)：都道府県 別にみた身長の発育年齢に対する都市化の影響につ いて, 日衛誌，35(4), 676-683

中村 正, 湯川幸一, 森本和枝, 平田文夫, 池鯉䱦治 明, 池田高士, 田原靖昭, 菅原正志, 石原結美 (1981)： 九州, 沖縄地方の学童・生徒体位と同地方住民の栄 養摂取水準の時代的推移，民族衛生，47(3), 120-137 総理府統計局 (1980)：昭和55年, 国勢調查報告, 第 1 巻, 人口総数, 日本統計協会, 昭和 57 年 10 月発行 (東 京), 29

田中 諭(1979)：出生時の体位および諸条件がその 後の心身の発育に及ぼす影響一回顧的コホート研究 一, 日公衛誌，26(3), 135145

渡辺恭子, 上田礼子(1982)：身長・体重の追跡的研究 一カウプ指数を中心に一，民族衛生，48(3), 142-149 (受稿 1986, 5 , 14) 